\title{
Influence of (hydrous) ethanol blends on (particle) emissions of small 2-\& 4-stroke scooters Part 2
}

\begin{abstract}
The objectives of the present work are to investigate the regulated and unregulated (particle) emissions of a classical and modern 2-stroke and a typical 4-stroke scooter with different ethanol blend fuels. There is also comparison of two different ethanol fuels: pure ethanol (E) and hydrous ethanol (EH) which contains 3.9\% water and is denatured with $1.5 \%$ gasoline. Special attention is paid in this research to the hydrous ethanol, since the production costs of hydrous ethanol are much less than those for (dry) ethanol.
\end{abstract}

Key words: ethanol, particle emission,2-stroke engines, scooters

\section{Wpływ mieszanek etanolowych na emisję cząstek stałych z małych skuterów dwu- i czterosuwowych Część 2}

\begin{abstract}
W artykule przedstawiono badanie uregulowanych i nieuregulowanych prawnie emisji czastek dla klasycznego i nowoczesnego skutera 2-suwowego i typowego skutera 4-suwowego zasilanych paliwami o różnym udziale etanolu. Ponadto zamieszczono porównanie dwóch różnych paliw etanolowych: czystego etanolu (E) $i$ wodnego etanolu (EH) zawierajacego 3,9\% wody i skażonego 1,5-procentowym stężeniem benzyny. Szczególnie skupiono sie na badaniach wodnego etanolu, od chwili, gdy koszty produkcji etanolu z dodatkiem wody okazaty się mniejszy niż etanolu bez takiego dodatku.
\end{abstract}

Słowa kluczowe: etanol, emisja czastek stałych, silniki 2-suwowe, skutery

\section{Results}

\subsection{Piaggio Typhoon}

The first test were performed with original tuning of the air-fuel ratio and without catalyst.

Before and after tests the mixture tuning was controlled at idling (without SAS). There were following values:

\begin{tabular}{|l|l|l|}
\hline Before tests & CO idl. $2.0 \%$ & $\mathrm{n}=1770 \mathrm{rpm}$ \\
\hline After tests & CO idl. $2.2 \%$ & $\mathrm{n}=1770 \mathrm{rpm}$ \\
\hline
\end{tabular}

Figure 5 gives an overview of limited emission components in the ECE 47 driving cycle with both ethanol types E \& EH.

Regarding $\mathrm{CO}, \mathrm{HC}$ and $\mathrm{NO}_{\mathrm{x}}$ three overlapping effects are visible:

- leaning of mixture by increasing ethanol portion,

- lowering the combustion peak temperatures and $\mathrm{NO}_{x}$ formation with increasing ethanol portion,

- retarded combustion, increased cyclic irregularities of combustion and increasing $\mathrm{HC}$-emissions with ethanol and with growing ethanol share.

The hydrous ethanol increases further the effect of leaning.

According to the driver there is remarkable roughness of operation and weak acceleration aptitude with ethanol, even E10, to the extend, that it would be unacceptable for the market.

\section{Wyniki*}

\subsection{Skuter Piaggio Typhoon}

Pierwsze badania przeprowadzono przy oryginalnym ustawieniu stężenia mieszanki powietrzno-paliwowej i bez katalizatora. Stężenie mieszanki na biegu luzem było sprawdzane przed i po testach (bez SAS). Otrzymano następujące wartości:

\begin{tabular}{|l|l|l|}
\hline Przed badaniami & CO 2,0\% dla biegu luzem & $\mathrm{n}=1770 \mathrm{obr} / \mathrm{min}$ \\
\hline Po badaniach & CO 2,2\% dla biegu luzem & $\mathrm{n}=1770 \mathrm{obr} / \mathrm{min}$ \\
\hline
\end{tabular}

Rysunek 5 dotyczy przeglądu ograniczonych elementów składowych emisji w cyklu jezdnym ECE 47 dla obu typów etanolu E i EH.

$\mathrm{W}$ odniesieniu do $\mathrm{CO}, \mathrm{HC}$ i $\mathrm{NO}_{\mathrm{x}}$ widoczne są trzy nachodzące na siebie zjawiska:

- zubożenie mieszanki przez zwiększenie udziału etanolu, - obniżenie wartości maksymalnych temperatur i powstawania $\mathrm{NO}_{\mathrm{x}}$ przy wzroście udziału etanolu,

\footnotetext{
* Wyniki zamieszczone w niniejszej części artykułu dotyczą badań nad oddziaływaniem mieszanek etanolowych na emisję cząstek stałych z silników spalinowych małych skuterów dwu- oraz czterosuwowych i stanowią kontynuację rozważań autorów pracy nad powyższą problematyką naukową podjętych w pierwszej części artykułu, który został opublikowany w Combustion Engines/Silniki Spalinowe nr 1/2011.
} 


\section{ECE 47}
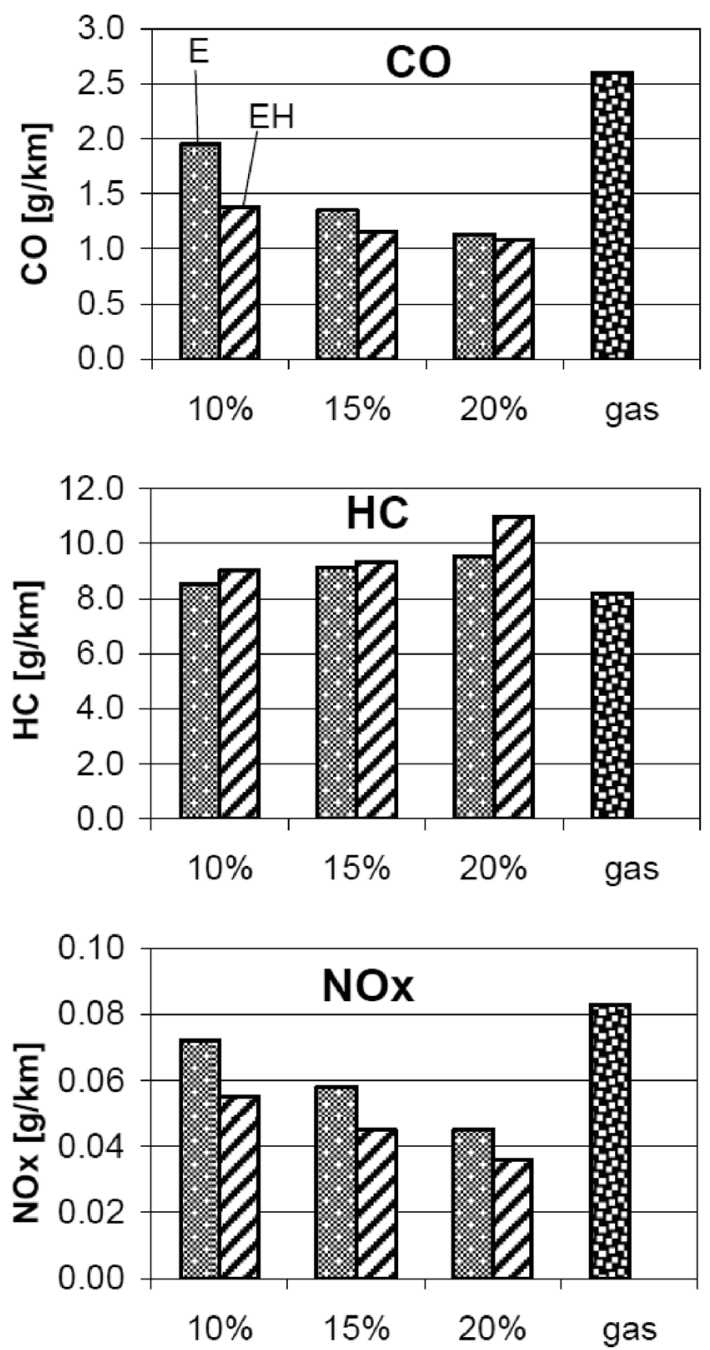

Fig. 5. Limited emissions with different fuels. Piaggio Typhoon, dummy, $\mathrm{CO}, \mathrm{HC}$, NOx bag values

Rys. 5. Ograniczone wartości emisji dla różnych rodzajów paliw. Skuter Piaggio Typhoon, bez reaktora, CO, HC, NOx wartości rozcieńczone

The volumetric fuel consumption in Fig. 6a increases with growing E-content. This on one hand according to the lower heat value of the blend fuels. On the other hand it must be assumed, that due to the irregular combustion there is a slight deterioration of the engine effective efficiency. The comparison of energy consumption (bars on the right side) eliminates the influence of heat value and confirms the last assumption.

With ethanol there is increased exhaust gas temperature (measured $30 \mathrm{~cm}$ after tailpipe) due to a retarded combustion and higher cyclic dispersion. The working cycles with a retarded heat release offer much higher temperature of exhaust gas. In cycles with failing combustion part of fuel in the exhaust line may cause exothermic heating also without oxycat.

The use of ethanol enables lower maximum speed. The hydrous ethanol generally increases the observed effects.
- opóźnienie spalania, wzrost okresowych nieregularności spalania i wzrastające emisje HC dla etanolu i rosnącego udziału etanolu.

Wodny etanol dodatkowo zwiększa zjawisko zubożenia.

Zdaniem kierowcy pojazdu dla etanolu a nawet etanolu E10 występuje znaczna nierównomierność pracy i niewielka zdolność do przyspieszenia o wartość, która byłaby nie do przyjęcia na rynku.

Objętościowe zużycie paliwa (rys. 6a) wzrasta wraz $\mathrm{z}$ rosnącą zawartością E (etanolu). Jest to z jednej strony zgodne z dolną wartością opałową dla mieszanek paliw. Z

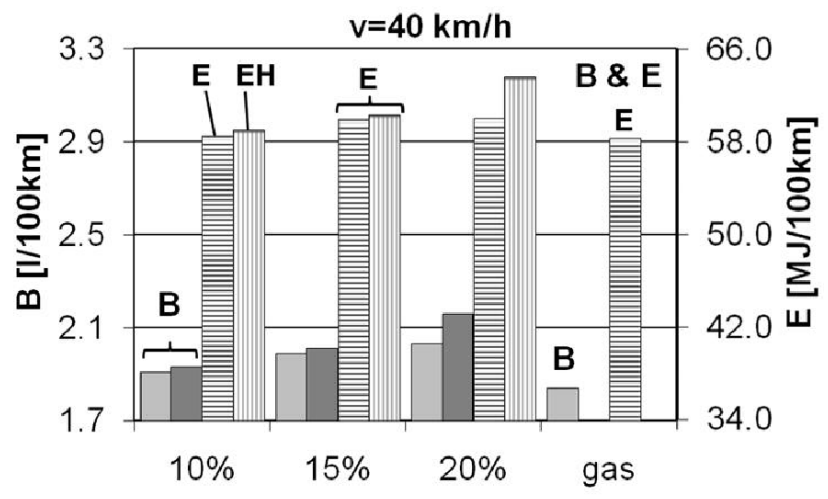

Fig. 6a. Fuel \& energy consumption at $40 \mathrm{~km} / \mathrm{h}$ with different fuels. Piaggio Typhoon, dummy

Rys. 6a. Zużycie paliwa i energii dla różnych paliw przy prędkości $40 \mathrm{~km} / \mathrm{h}$. Skuter Piaggio Typhoon, bez reaktora
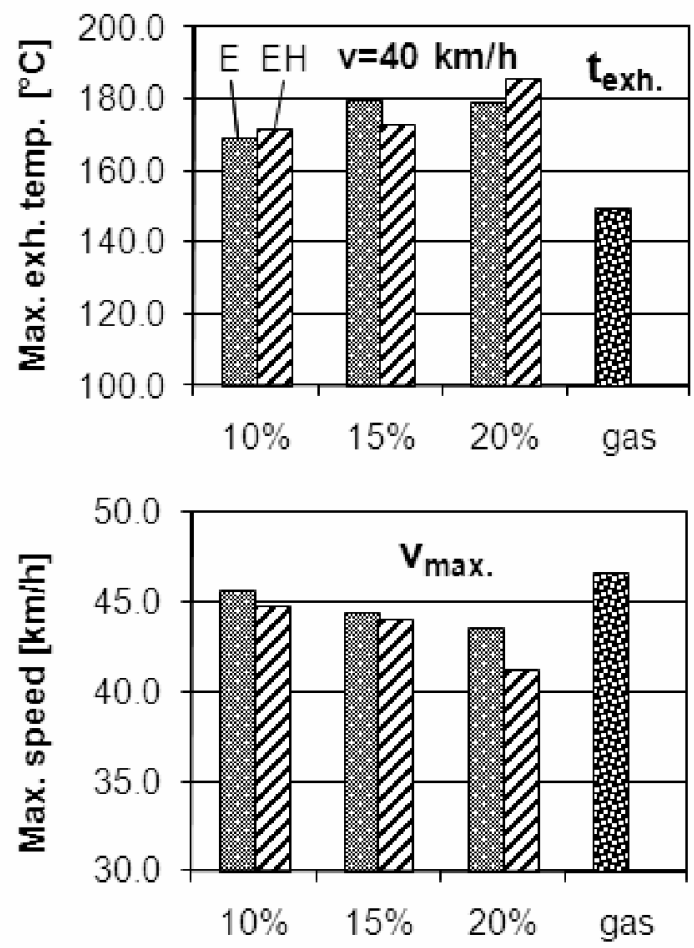

Fig. 6b. Exhaust temperatures (tailpipe) at $40 \mathrm{~km} / \mathrm{h}$ and maximum speed with different fuels. Piaggio Typhoon, dummy

Rys. 6b. Temperatura spalin (w przewodzie wylotowym silnika) przy prędkości $40 \mathrm{~km} / \mathrm{h}$ i maksymalnej prędkości dla różnych paliw. Skuter Piaggio Typhoon, bez reaktora 


\section{Vconst $=40 \mathrm{~km} / \mathrm{h}$}
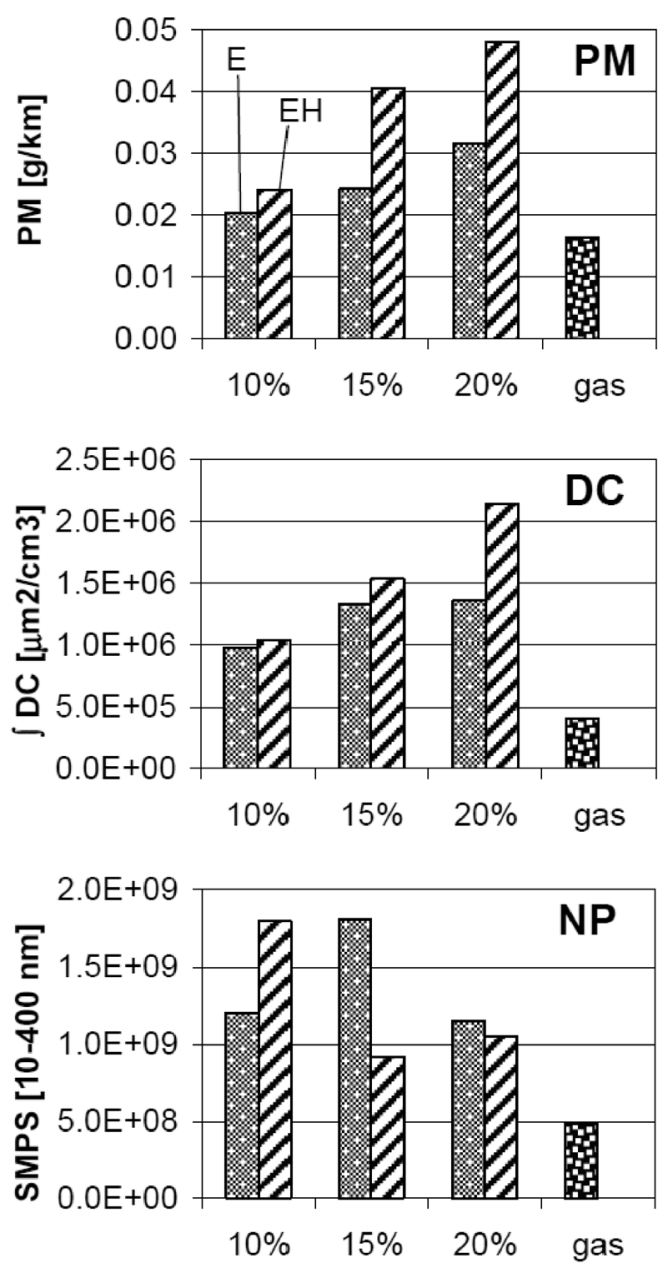

Fig. 7. Particle emissions with different fuels. Piaggio Typhoon, dummy

Rys. 7. Emisje cząstek statych dla różnych paliw. Skuter Piaggio Typhoon, bez reaktora

Figure 7 represents the integral NP-emissions with all fuels at constant speed $\mathrm{v}=40 \mathrm{~km} / \mathrm{h}$.

Beside the particle mass (PM) there are integrated DCsignals over the last 10 min of constant speed and integrated NP-count concentrations over the particle sizes in the SMPS measuring range $(10-400 \mathrm{~nm})$.

The NanoMet signal is converted to the values responding to the undiluted volume concentrations in the exhaust gas.

DC (diffusion charging sensor) measures the total particle surface independent of the chemical properties. It indicates the solids and the condensates.

In this figure only DC is represented, since PAS indicates zero-values. Very often by the $2-S$ exhaust aerosol the solids are enveloped by the condensates (SOF) and are not detected by PAS (which is sensitive only to the carbonaceous surface). The total aerosol surface DC indicates all particles and correlates usually very well with the particle mass PM for this type of aerosol.

It can be stated, that with increasing share of ethanol the summary surface of NP's (DC) increases. drugiej strony należy przyjąć, że na skutek nieregularnego spalania występuje nieznaczne pogorszenie sprawności ogólnej silnika. Porównanie zużycia energii (słupki po prawej stronie) eliminuje wpływ wartości cieplnej i potwierdza ostatnie założenie.

W przypadku etanolu występuje podwyższona temperatura spalin (mierzona $30 \mathrm{~cm}$ za przewodem wylotowym silnika) wskutek opóźnionego spalania i wyższej okresowej dyspersji. Cykle robocze z opóźnionym uwalnianiem ciepła dają znacznie wyższą temperaturę spalin. Cykle z niepełnym spalaniem części paliwa mogą powodować w linii wylotu spalin grzanie egzotermiczne także bez utleniającego reaktora katalitycznego.

Zastosowanie etanolu umożliwia uzyskanie mniejszej prędkości maksymalnej. Ogólnie wodny etanol jest przyczyną nasilenia się obserwowanych zjawisk.

Na rysunku 7 przedstawiono zintegrowaną emisję nanocząstek NP dla wszystkich paliw przy stałej prędkości $\mathrm{v}=40 \mathrm{~km} / \mathrm{h}$.

Oprócz masy cząstek stałych (PM) występują zintegrowane sygnały czujnika rozcieńczenia ładunku DC w czasie ostatnich 10 min stałej prędkości i zintegrowane obliczone stężenie nanocząstek dla wielkości cząstek z zakresu pomiarowego - skaningowego analizatora wymiarowego cząstek stałych SMPS [10-400 nm].

Sygnał z NanoMet przekształcony jest na wartości odpowiadające nierozcieńczonym stężeniom objętościowym spalin.

Czujnik DC (czujnik rozcieńczenia ładunku) mierzy całkowitą powierzchnię cząstki, niezależnie od właściwości chemicznych. Wskazuje on cząstki stałe i ciecze.

$\mathrm{Na}$ rysunku 7 przedstawiono jedynie rozcieńczenie ładunku DC, ponieważ fotoelektryczny czujnik aerozolu PAS wskazuje wartości zerowe. Bardzo często w aerozolu w spalinach z silników 2-suwowych cząstki stałe są osłonięte kondensatami, frakcjami rozpuszczalnymi cząstki stałej (SOF) i nie są wykrywane przez czujnik PAS (który jest czuły jedynie w odniesieniu do powierzchni węglowych). Całkowita powierzchnia aerozolu czujnika DC wskazuje wszystkie cząstki i zazwyczaj bardzo dobrze koreluje z masą cząstek stałych PM dla tego typu aerozolu.

Można stwierdzić, że wraz ze wzrostem udziału etanolu rośnie sumaryczna powierzchnia nanocząstek NP (DC).

Ogólnie poziom emisji cząstek stałych PM i nanocząstek NP dla paliw etanolowych jest większy niż poziom emisji dla benzyny. Taka tendencja, na pierwszy rzut oka, jest sprzeczna z oczekiwaniami, gdyż etanol jako dawca tlenu powinien poprawiać spalanie. Niemniej jednak istnieją inne zjawiska w kompleksowych procesach fizykochemicznych zachodzących w silniku, które nadmiernie kompensują ten pierwszy wpływ dostarczenia tlenu:

- Masa cząstek stałych i nanoczątek w małych silnikach 2-suwowych składa się głównie z oleju smarującego, niespalonego lub częściowo spalonego, lub z kondensatów ciężkiego oleju HO.

- Mechanizmy produkcji cząstek są nie tylko wynikiem samego spalania, lecz również szybkiego chłodzenia przepływu przez ścianki podczas przepłukiwania (wpływ na 
The PM- and NP-emission level with ethanol fuels is generally higher, than with gasoline. This tendency is at first glance contrary to the expectations since ethanol, as a donator of oxygen should improve the combustion. Nevertheless there are other facts in the complex physico-chemical processes running in the engine, which overcompensate this first influence of oxygen donation:

- particle mass and nanoparticles in a small 2-stroke engine consist mostly of lube oil as unburned, partially burned, or condensates of heavy $\mathrm{HC}$,

- the mechanisms of particle production are not only due to the combustion itself, but also to the wall quenching, flow during the scavenging (effects on residual gas ratio) and condensation speed in the exhaust system,

- since ethanol generally lowers the process temperatures it influences all the mechanisms mentioned above,

- during the previous research with Alkylat gasoline and with different lube oils [3], it was stated, that the chemistry i.e. the HC matrix in the exhaust gas plays a role for the condensation effects and influences clearly the NP \& PM production,

- during the tests with Piaggio Typhoon the engine operation with ethanol fuels was not as smooth, as with gasoline, the ability of acceleration was much weaker and the cyclic dispersion of the engine working cycles (due to leaning by ethanol) is believed to be the most important influence on the higher particle emissions.

For SMPS, Fig. 8 the tendencies are not monotone, but the differences are, as for this parameter in the range of (emiting + measuring) dispersion. Furthermore there are balancing effects between nuclei- and accumulation modes of the respective PSD's, which slightly varies from measurement to measurement.

Why are the maxima of the NP concentrations with ethanol fuels much higher (up to 3.4 times), than with gasoline? The maxima are in the size range between approx. 40 and 70 $\mathrm{nm}$, which is for the Diesel exhaust aerosol in the lower part of accumulation mode. In the present case of 2-S engine the mechanisms and the nature of NP aerosol is quite different, than for Diesel.

Three effects can be suggested for this observed increase of particle counts:

- improved oxidation of bigger oil droplets during the combustion with ethanol, which generates more of smaller particles, or some solids in the lowest size range,

- store and release effects of some particles or substances from the combustion chamber or exhaust system walls, which offer some precursors of the observed nanoparticles (washing effects, [12]),

- changed effects of spontaneous condensation in the exhaust system due to changed HC-matrix and eventually generation of new substances (the first effect is known from the research with different oils and fuels on 2-S scooters [3] and the second effect is know from the research with water emulsion fuels on Diesel engines).

The repetitions with Piaggio Typhoon were performed to test the driving quality and the emissions with lower
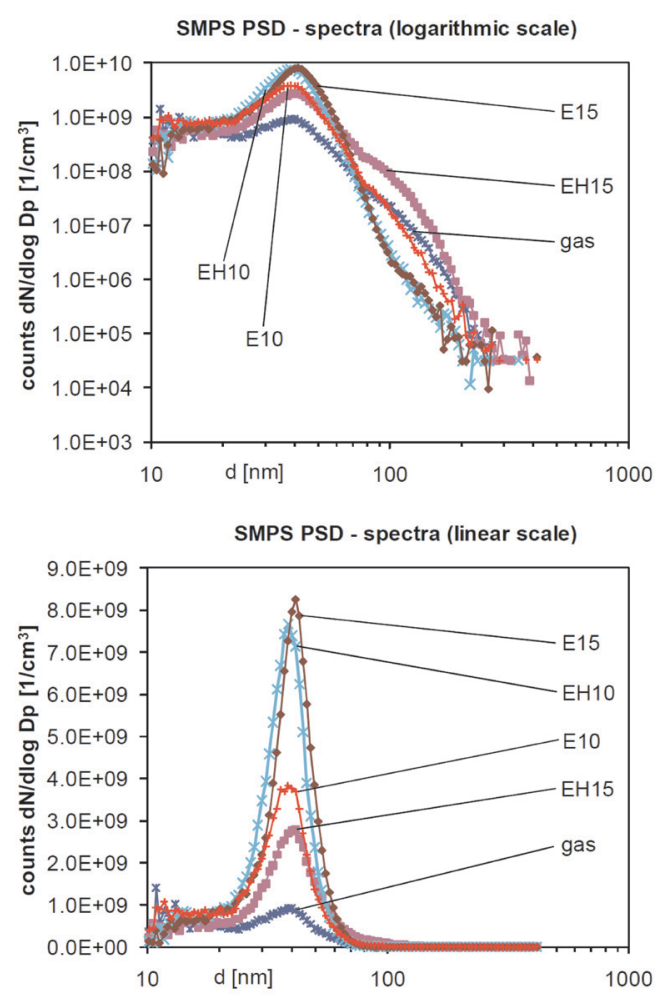

Fig. 8. SMPS particle size distribution spectra at constant speed $40 \mathrm{~km} / \mathrm{h}$, warm, with different fuels. Piaggio Typhoon, dummy

Rys. 8. Widmo rozkładu wymiarowego czastek SMPS przy stałej prędkości $40 \mathrm{~km} / \mathrm{h}$ dla cieptego silnika, dla różnych paliw. Skuter Piaggio Typhoon, bez reaktora

wielkość reszty spalin) i prędkości kondensacji w systemie wylotowym silnika.

- Ponieważ etanol generalnie obniża temperatury procesowe, to wpływa na wszystkie mechanizmy wymienione wyżej.

- Podczas poprzednich badań z benzyną Alkylat i różnymi olejami smarującymi [3] stwierdzono, że procesy chemiczne, tj. jednorodne struktury $\mathrm{HC} \mathrm{w}$ spalinach, mają znaczenie dla zjawisk kondensacji i wyraźnie wpływają na powstawanie NP i PM.

- Podczas prób skutera Piaggio Typhoon praca silnika na paliwach etanolowych nie była równomierna, jak w przypadku benzyny, zdolność przyspieszania była mniejsza i uważa się, że cykliczne rozproszenie roboczych cykli silnika (wskutek zubożenia przez etanol) ma najważniejszy wpływ na większą emisję cząstek.

Przy zastosowaniu analizatora SMPS (rys. 8) tendencje nie są monotoniczne, lecz występuje różnica co do tego parametru w zakresie dyspersji (emisja + pomiar). Ponadto istnieją efekty bilansowania pomiędzy trybami jądrowym i akumulacyjnym odpowiedniego rozkładu wymiarowego cząstek DPS, który nieznacznie zmienia się w miarę dokonywania pomiarów. Dlaczego maksima stężeń nanocząsteczek NP są dużo wyższe dla paliw etanolowych (do 3,4 razy wieksze) niż dla benzyny? Maksima znajdują się w zakresie wielkości pomiędzy (w przybliżeniu) 40 i 70 nm, który w przypadku aerozolu wylotowego z silnika ZS znajduje się w dolnej części trybu akumulacyjnego. 
portions of Ethanol blended and with richer basic tuning of the engine.

The basic tuning of air/fuel-ratio is set at idling (by measuring $\mathrm{CO}$ ) and has for this type of simple carburator influence on the air/fuel dosing up to higher part load operation of the engine.

The mixture tuning was controlled at idling (without SAS): before, after and during the tests. There were following values:

\begin{tabular}{|l|l|l|}
\hline \multicolumn{3}{|l|}{ Original mixture tuning } \\
\hline Before tests & CO idl. 3.0\% & $\mathrm{n}=1670 \mathrm{rpm}$ \\
\hline After tests & CO idl. $2.8 \%$ & $\mathrm{n}=1800 \mathrm{rpm}$ \\
\hline Rich mixture Tuning & \multicolumn{2}{|l}{} \\
\hline Before tests & CO idl. $5.3 \%$ & $\mathrm{n}=1700 \mathrm{rpm}$ \\
\hline After tests & CO idl. $5.0 \%$ & $\mathrm{n}=1340 \mathrm{rpm}$ \\
\hline
\end{tabular}

Comparing the original mixture tuning with the previous values a quite poor stability of idling setting after longer period (3 months) can be remarked.

Figure 9 shows the comparison of limited emissions at constant speed.

Figure 10 represents the (nano)particle emissions. The variants with richer basic tuning were designed with " $r$ ".

The richer tuning provokes generally lower particle count concentrations in the nuclei mode. There are more agglomeration effects and the particle mass (which has similar values for all variants) is produced by particles of bigger sizes.

Another clear influence of the richer tuning is a satisfactory driveability of the vehicle. The lower cyclic dispersion of combustion has positive impact on $\mathrm{HC}$, which stays nearly constant in spite of the richer mixture. The lower cyclic irregularities influence the mechanisms of NP-production in the combustion chamber and in the exhaust line.

The richer tuning increases the tolerance of ethanol application and makes it possible to use E10 with similar values of particle mass and fuel consumption as the original fuel but with lower $\mathrm{NO}_{\mathrm{x}}$.

With the original, leaner tuning there is increased exhaust gas temperature due to a retarded combustion and higher cyclic dispersion.

There are some differences of shape of the SMPS PSDspectra between pervious measurements (June '08) and the later repetitions (Sept. '08).

The differences are particularly visible in the nucei mode $(\mathrm{d}<30 \mathrm{~nm})$, where the spontaneous condensation is a dominant effect. The nuclei mode is a very sensitive indicator of different influences, like: differences of tuning, irregularities of oil dosing and mixing with air, deposits of oil in the crankcase, or in the silencer (from cold starting), irregularities of carubator (dosing and mixture preparation) etc.

It was stated in the previous research, that the 2-S scooters are not stable concerning the nanoparticles emissions and the PSD's over longer time periods.

Looking on average results of leaner and richer engine setting in Fig. 10 it can be stated that there is no clear
Dla silnika dwusuwowego mechanizmy i charakter aerozolu nanocząsteczkowego NP są zupełnie inne niż dla silnika ZS.

Można zasugerować występowanie trzech zjawisk dla obserwowanego wzrostu zliczeń cząstek:

- Lepsze utlenienie większych kropli oleju podczas spalania z etanolem, które wytwarza więcej mniejszych cząstek, lub pewnych ciał stałych $\mathrm{z}$ najmniejszego zakresu wielkości.

- Efekt magazynowania i uwalniania pewnych cząstek lub substancji z komory spalania lub ścianek układu wylotowego, który dostarcza ściśle określonych prekursorów obserwowanych nanocząstek (efekt wymywania [12]).

- Zmienione efekty spontanicznej kondensacji w układzie wylotowym wskutek zmienionej jednorodnej struktury HC i ostateczne powstawanie nowych substancji (pierwszy efekt znany jest $\mathrm{z}$ badań różnych olejów i paliw w skuterach 2-suwowych [3], a drugi znany jest z badań paliw wodno-emulsyjnych dla silników ZS).

Przeprowadzono powtórne badania dla skutera Piaggio Typhoon w celu sprawdzenia jakości jazdy i emisji dla mniejszych udziałów etanolu i przy podstawowym ustawieniu silnika na spalanie bogatszej mieszanki.

Podstawowe ustawienie stężenia mieszanki powietrznopaliwowej odbywa się na biegu luzem (przez pomiar CO) i ma dla tego typu gaźnika wpływ na dozowanie wartości powietrze/paliwo aż do pracy silnika przy wyższych obciążeniach częściowych.

Ustawienie mieszanki było kontrolowane na biegu luzem (bez systemu wtórnego powietrza SAS): przed, po i podczas badań. Otrzymano następujące wartości:

\begin{tabular}{|l|l|l|}
\hline \multicolumn{4}{|l|}{ Początkowe ustawienie mieszanki } \\
\hline Przed badaniami & CO na biegu luzem 3,0\% & $\mathrm{n}=1670 \mathrm{obr} / \mathrm{min}$ \\
\hline Po badaniach & CO na biegu luzem $2,8 \%$ & $\mathrm{n}=1800 \mathrm{obr} / \mathrm{min}$ \\
\hline Ustawienia mieszanki bogatej \\
\hline Przed badaniami & CO na biegu luzem 5,3 \% & $\mathrm{n}=1700 \mathrm{obr} / \mathrm{min}$ \\
\hline Po badaniach & CO na biegu luzem 5,0 \% & $\mathrm{n}=1340 \mathrm{obr} / \mathrm{min}$ \\
\hline
\end{tabular}

Porównując początkowe ustawienia mieszanki z poprzednimi wartościami, można zauważyć całkiem słabą stabilność nastawy dla biegu luzem po dłuższym czasie (3 miesiące).

Na rysunku 9 przedstawiono porównanie ograniczonych emisji przy stałej prędkości.

Na rysunku 10 przedstawiono emisję nanocząstek. Warianty pomiarowe dla wzbogaconego ustawienia podstawowego zostały oznaczone za pomocą " $r$ ".

Wzbogacone ustawienie wywołuje niższe stężenia zliczanych cząstek w trybie jądrowym. Występuje więcej efektów aglomeracyjnych i masa cząstek stałych (która ma podobne wartości dla wszystkich wariantów) jest tworzona przez cząstki o większych rozmiarach.

Innym wyraźnym efektem wzbogaconego ustawienia jest zdolność do prowadzenia pojazdu. Niższa cykliczna dyspersja spalania ma pozytywny wpływ na emisję węglo- 

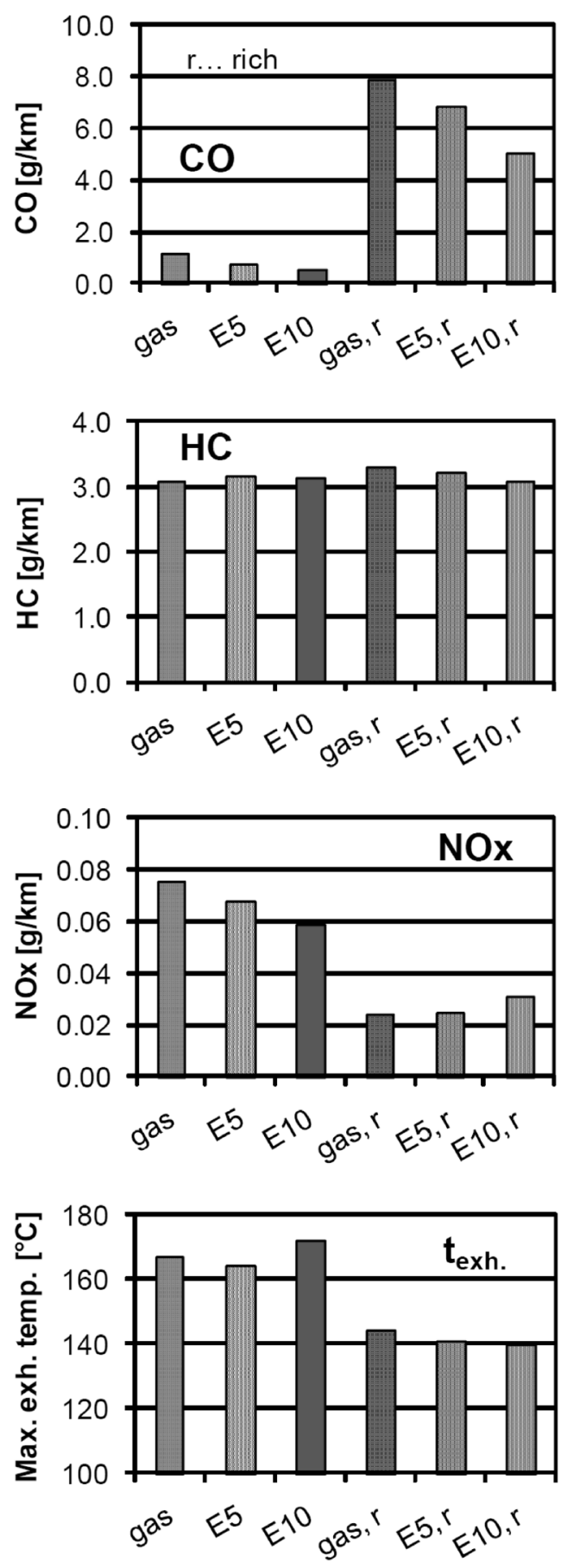

Fig. 9. Limited emissions and exhaust temperatures (tailpipe) with different fuels; lean - rich. Piaggio Typhoon; dummy; $\mathrm{CO}, \mathrm{HC}, \mathrm{NO}_{\mathrm{x}}$ bag values

Rys. 9. Ograniczone emisje i temperatury spalin (w przewodzie wylotowym silnika) dla różnych paliw; ubogich - wzbogaconych. Skuter Piaggio Typhoon bez reaktora; wartości rozcieńczone CO, $\mathrm{HC}, \mathrm{NO}_{x}$

difference of PM-emissions, but clearly higher NPcount concentrations for the leaner variant. This higher NP-values are caused by the higher nuclei mode, which in turn is mostly influenced by the changed conditions of the spontaneous condensation and nucleation in the exhaust system.
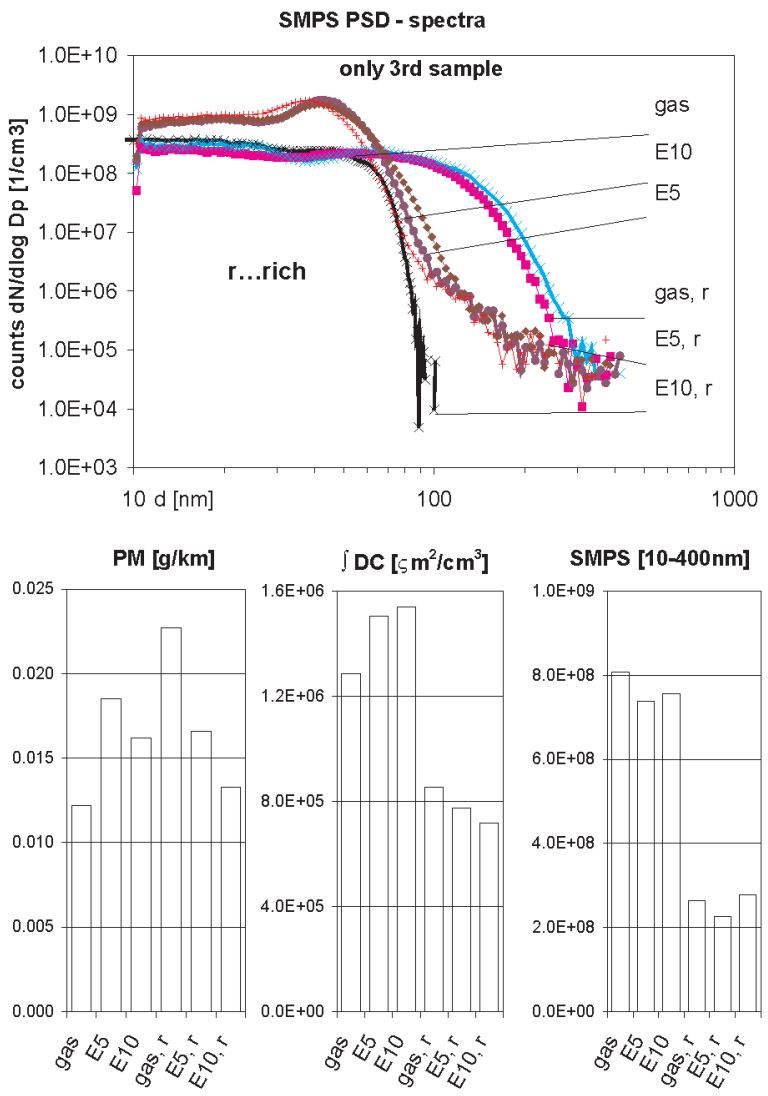

Fig. 10. Particle mass and nanoparticles at constant speed $40 \mathrm{~km} / \mathrm{h}$, warm, with different fuels; lean - rich. Piaggio Typhoon, dummy

Rys. 10. Masa cząsteczkowa i nanocząstki przy stałej prędkości $40 \mathrm{~km} / \mathrm{h}$, dla rozgrzanego silnika, przy różnych paliwach; ubogich - wzbogaconych. Skuter Piaggio Typhoon, bez reaktora

wodorów HC, która pozostaje prawie niezmieniona pomimo wzbogacenia mieszanki. Niższe cykliczne nierównomierności wpływają na mechanizm tworzenia nanocząstek w komorze spalania i w linii wylotu spalin.

Wzbogacone ustawienie zwiększa tolerancję dla zastosowania etanolu i umożliwia stosowanie E10 przy podobnych wartościach masy cząstki i zużycia paliwa jak dla paliwa wyjściowego, ale przy mniejszej emisji $\mathrm{NO}_{x}$.

W sytuacji początkowego ustawienia uboższej mieszanki występuje zwiększona temperatura spalin w wyniku opóźnionego spalania i wyższej cyklicznej dyspersji.

Istnieją różnice kształtu widm analizatora wymiarowego cząsteczek stałych SMPS dla rozkładu wymiarowego cząstek PSD otrzymanych podczas wcześniejszych pomiarów (z czerwca '08) i późniejszych powtórzonych pomiarów (z września '08). Różnice są szczególnie wyraźne dla trybu jądrowego ( $<30 \mathrm{~nm})$, dla którego spontaniczna kondensacja jest dominującym efektem. Tryb jądrowy stanowi bardzo czuły wskaźnik różnych wpływów, takich jak: różnice ustawienia mieszanki, nieregularności w dozowaniu oleju i mieszania z powietrzem, osadzania się oleju w skrzyni korbowej lub w tłumiku (przy zimnym starcie), nieregularności w gaźniku (dozowanie i przygotowanie mieszanki) itd.

We wcześniejszych badaniach stwierdzono, że skutery z silnikami 2-suwowymi nie są stabilne ze względu na emisje 


\subsection{Kreidler Florett}

Before, during and after tests the mixture tuning was controlled at idling. There were following values:

\begin{tabular}{|l|l|l|}
\hline Before tests & CO idl.4.36\% & $\mathrm{n}=1630 \mathrm{rpm}$ \\
\hline After tests & CO idl. $5.97 \%$ & $\mathrm{n}=1750 \mathrm{rpm}$ \\
\hline
\end{tabular}

The tuning of engine mixture is very rich and there is no possibility to change it.

Figure 11 gives an overview of all limited gaseous emission components in the driving cycles.

Regarding $\mathrm{CO}, \mathrm{HC}$ and $\mathrm{NO}$ following effects are visible:

- leaning of mixture by increasing ethanol portion (by lowering $\mathrm{CO}$ and $\mathrm{HC}$ ),

- increasing the combustion peak temperatures and $\mathrm{NO}_{\mathrm{x}}$ formation with increasing ethanol portion and strengthening of these effects with hydrous ethanol, (moving from low Lambda, very rich towards Lambda 1, less rich).

According to the driver there was no problem of driveability with the highest ethanol share E15, or EH15. nanocząstek i rozkłady wymiarowe cząstek PSD w okresie dłuższych przedziałów czasowych.

Analizując na rys. 10 średnie wyniki dla nastaw silnika dla mieszanek wzbogacanych i zubożonych, można stwierdzić, że nie ma wyraźnej różnicy w wielkościach emisji PM, ale stężenia zliczeń nanocząstek są wyraźnie większe dla wariantu ze zubożoną mieszanką. Wyższe wartości NP spowodowane są przez wyższy tryb jądrowy, na który z kolei mają największy wpływ zmienione warunki spontanicznej kondensacji i nukleizacji w układzie wylotowym.

\subsection{Skuter Kreidler Florett}

Ustawienia mieszanki były kontrolowane na biegu luzem przed, podczas i po badaniach. Otrzymano następujące wartości:

\begin{tabular}{|l|c|c|}
\hline Przed badaniami & CO dla biegu luzem 4,36\% & $\mathrm{n}=1630 \mathrm{obr} / \mathrm{min}$ \\
\hline Po badaniach & CO dla biegu luzem $5,97 \%$ & $\mathrm{n}=1750 \mathrm{obr} / \mathrm{min}$ \\
\hline
\end{tabular}

Ustawiona mieszanka silnika ma wartość odpowiadającą mieszance wzbogaconej i nie ma możliwości zmiany nastawy.
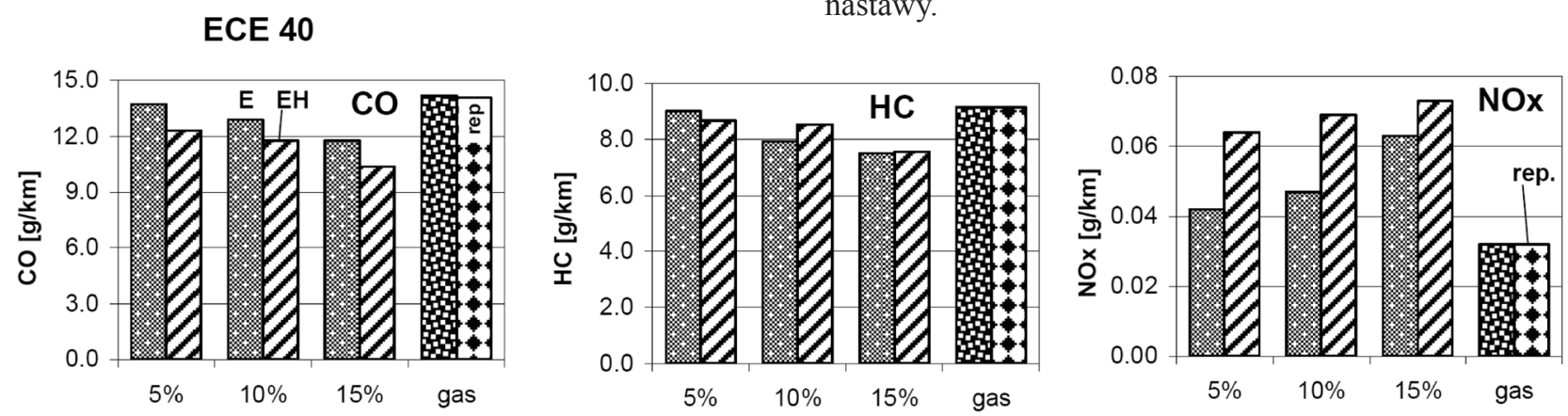

Fig. 11. Comparison of limited emissions with different fuels. Kreidler Florett, $\mathrm{CO}, \mathrm{HC}, \mathrm{NO}_{\mathrm{x}}$ bag values

Rys. 11. Porównanie ograniczonych emisji dla różnych paliw

The volumetric fuel consumption is reduced due to the leaning of mixture and increased efficiency with the ethanol blend fuels, Fig. 12. There is in particular an advantage of EH15, over E15.

Also the exhaust temperature at constant speed generally decreases with higher ethanol rate. With hydrous ethanol this decrease is less pronounced, which is an effect of stronger
Na rysunku 11 zaprezentowano przegląd wszystkich gazowych elementów ograniczonej emisji dla cykli jezdnych.

W odniesieniu do $\mathrm{CO}, \mathrm{HC}$ i $\mathrm{NO}_{\mathrm{x}}$ widoczne są następujące efekty:

- zubożenie mieszanki przez zwiększeniu udziału etanolu (przez obniżenie emisji CO i HC),
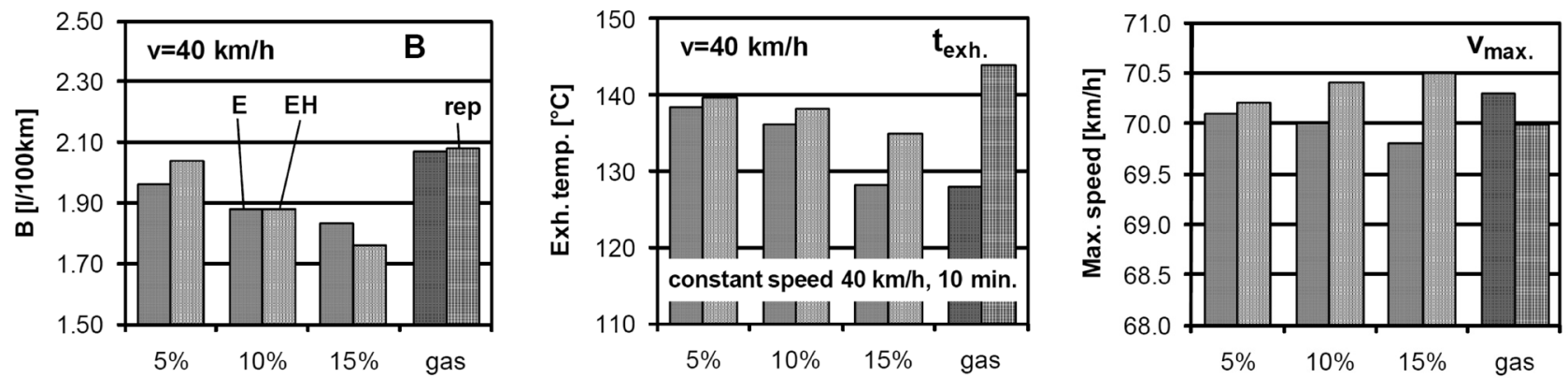

Fig. 12. Fuel consumption and exhaust tempe-ratures (tailpipe) at $40 \mathrm{~km} / \mathrm{h}$ and maximum speed with different fuels. Kreidler Florett Rys. 12. Zużycie paliwa oraz temperatury spalin (w przewodzie wylotowym silnika) przy prędkości $40 \mathrm{~km} / \mathrm{h}$ i prędkości maksymalnej dla różnych paliw. Skuter Kreidler Florett 


\section{Vconst $=40 \mathrm{~km} / \mathrm{h}$}
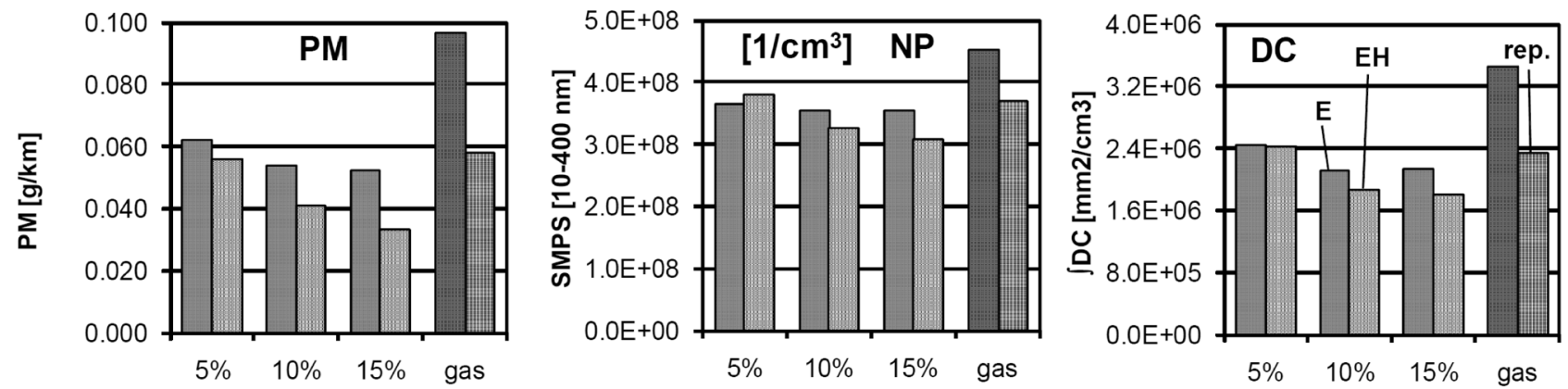

Fig. 13. Particle emissions with different fuels. Kreidler Florett

Rys. 13. Emisje cząstek dla różnych paliw. Skuter Kreidler Florett

leaning with $\mathrm{EH}$. Interesting is the influence on the maximum speed (maximum power), which even gives some advantages with hydrous ethanol.

In Figure 13 there are comparisons of: PM-values, integrated DC-signals over the last 10 min of constant speed and integrated NP-count concentrations over the particle sizes in the SMPS measuring range $10-400 \mathrm{~nm}$.

SMPS PSD - spectra (logarithmic scale)
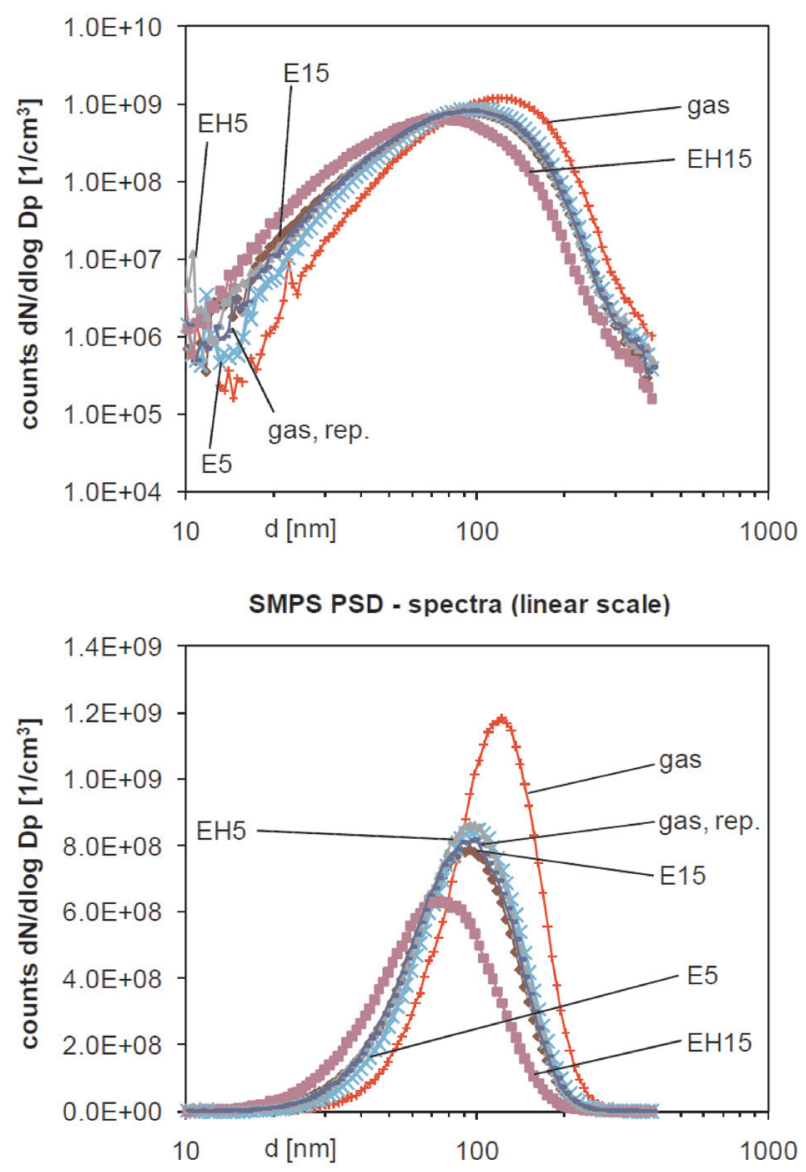

Fig. 14. SMPS particle size distribution spectra at constant speed 40 $\mathrm{km} / \mathrm{h}$, warm, with different fuels. Kreidler Florett

Rys. 14. Widma rozkładu wymiarowego cząstek przy stałej prędkości SMPS $40 \mathrm{~km} / \mathrm{h}$, dla cieptego silnika dla różnych paliw. Skuter Kreidler Florett
- zwiększenie wartości maksymalnych temperatur spalania oraz formowanie się $\mathrm{NO}_{\mathrm{x}}$ przy wzroście udziału etanolu oraz wzmocnienie tych efektów dla wodnego etanolu (przesuwanie się od niskiego współczynnika lambda, poprzez bardzo bogate mieszanki w kierunku lambda 1, do mniej bogatych).

Zgodnie z opinią kierowcy pojazdu nie zaobserwowano problemu związanego z kierowaniem pojazdem przy najwyższym udziale etanolu E15 lub EH15.

Objętościowe zużycie paliwa jest obniżone wskutek zubożenia mieszanki i zwiększonej wydajności dla paliw zmieszanych z etanolem. Na rysunku 12 szczególnie widoczna jest przewaga EH15 nad E15.

Generalnie również temperatura spalin przy stałej prędkości maleje dla większych udziałów etanolu. W odniesieniu do wodnego etanolu ten spadek jest mniej wyraźny, co jest efektem silniejszego zubożenia mieszanki przy EH. Interesujący jest wpływ na prędkość maksymalną (maksymalna moc), który wskazuje nawet przewagę wodnego etanolu.

Na rysunku 13 przedstawiono następujące porównania: wartości PM, zintegrowanych sygnałów czujnika rozcieńczenia ładunku DC podczas ostatnich 10 min stałej prędkości oraz zintegrowanych stężeń zliczeń nanocząstek NP-count analizatora SMPS dla rozmiarów cząstek z zakresu pomiarowego $10-400 \mathrm{~nm}$.

Można stwierdzić, że przy wzrastającym udziale etanolu sumaryczna powierzchnia nanocząstek NP (DC) maleje. DC maleje również w przypadku dodania wody. Taka sama zależność obowiązuje dla cząstek stałych PM (całkowita masa cząstek) oraz dla zintegrowanych zliczeń nanocząstek NP-counts.

Można także stwierdzić, że przy ustawieniu bogatej mieszanki etanol pomaga $\mathrm{w}$ utlenieniu prekursorowych substancji cząstek odpowiednio do zwiększonego stopnia mieszania. Zastosowanie uwodnionego etanolu (EH) nieznacznie zwiększa taką tendencję dzięki obecności wody.

Pomiary z użyciem analizatora SMPS rozpoczęto po cyklach jezdnych i po 5 minutach kondycjonowania przy takiej samej stałej prędkości $(40 \mathrm{~km} / \mathrm{h})$.

Na rysunku 14 przedstawiono wybrane widma rozkładu wymiarowego cząstek w skali logarytmicznej i liniowej. Widoczne jest, że zastosowanie etanolu przesuwa mak- 
It can be stated, that with increasing share of ethanol the summary surface of NP's (DC) decreases. DC decreases also with addition of water. The same is valid for the PM (total particle mass) and for integrated NP-counts.

It can be said, that for the rich tuning ethanol helps to oxidize the precursor substances of particles (according to the increased blend ratio). The application of hydrous ethanol (EH) increases slightly this tendency thanks to the presence of water.

The measurements with SMPS were started after the driving cycles and after $5 \mathrm{~min}$ conditioning at the same constant speed $(40 \mathrm{~km} / \mathrm{h})$.

Figure 14 represents some choosen PSD's in logarithmic and in linear scale. It is visible that the application of ethanol moves the maxima of the PSD's to lower counts and to lower median diameters (CMD). The influence of hydrous ethanol comparing to the pure ethanol is not visible, it is overlapped by the emission variability.

\subsection{Honda Zoomer}

Also for this 4-S scooter the mixture tuning was controlled at idling (with SAS) before and after tests. There were following values:

sima widm PSD w stronę niższych zliczeń i mniejszych obliczonych środkowych wartości średnic (CMD). Wpływ wodnego etanolu w porównaniu do czystego etanolu nie jest zauważalny; wartości te zazębiają się wskutek zmienności emisji.

\subsection{Skuter Honda Zoomer}

Również dla tego 4-suwowego skutera ustawienie mieszanki było kontrolowane na biegu luzem (z systemem powietrza wtórnego SAS) przed i po badaniach. Otrzymano następujące wartości:

\begin{tabular}{|l|c|c|}
\hline Przed badaniami & CO dla biegu luzem $2,5 \%$ & $\mathrm{n}=2020 \mathrm{obr} / \mathrm{min}$ \\
\hline Po badaniach & CO dla biegu luzem $3,1 \%$ & $\mathrm{n}=1950 \mathrm{obr} / \mathrm{min}$ \\
\hline
\end{tabular}

Na rysunkach 15, 16 i 17 przedstawiono najważniejsze wyniki: elementy gazowe wskazują na występowanie uboższego ustawienia przy wzrastającym udziale alkoholu zmniejszonych emisji CO i HC, wzrost emisji NO, tam gdzie wpływ uwodnionego etanolu jest nieznacznie większy.

Zużycie paliwa obniżone jest wskutek zubożenia mieszanki i wzrostu sprawności ogólnej silnika.

Istnieje niewielki wpływ zastosowanych paliw z etanolem na temperaturę spalin (przy $40 \mathrm{~km} / \mathrm{h}$ ) i na maksymalną prędkość. Przy zastosowaniu wodnego etanolu taki wpływ prawie nie występuje.

ECE 40
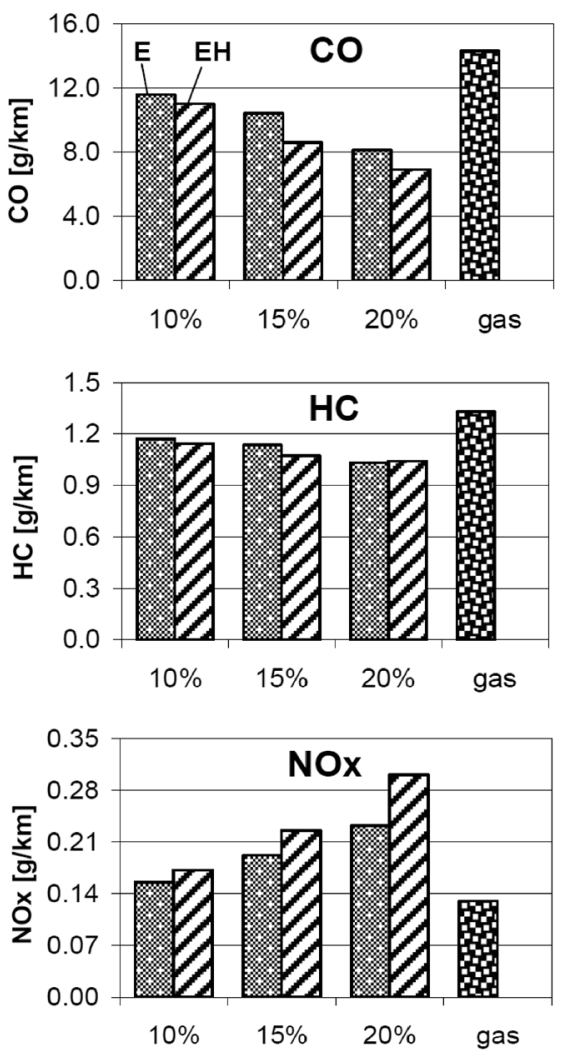

Fig. 15. Limited emissions with different fuels. Honda Zoomer, $\mathrm{CO}, \mathrm{HC}, \mathrm{NO}_{\mathrm{x}}$ bag values

Rys. 15. Obniżone emisje dla różnych paliw. Skuter Honda Zoomer, wartości rozcieńczone CO, $\mathrm{HC}, \mathrm{NO}$
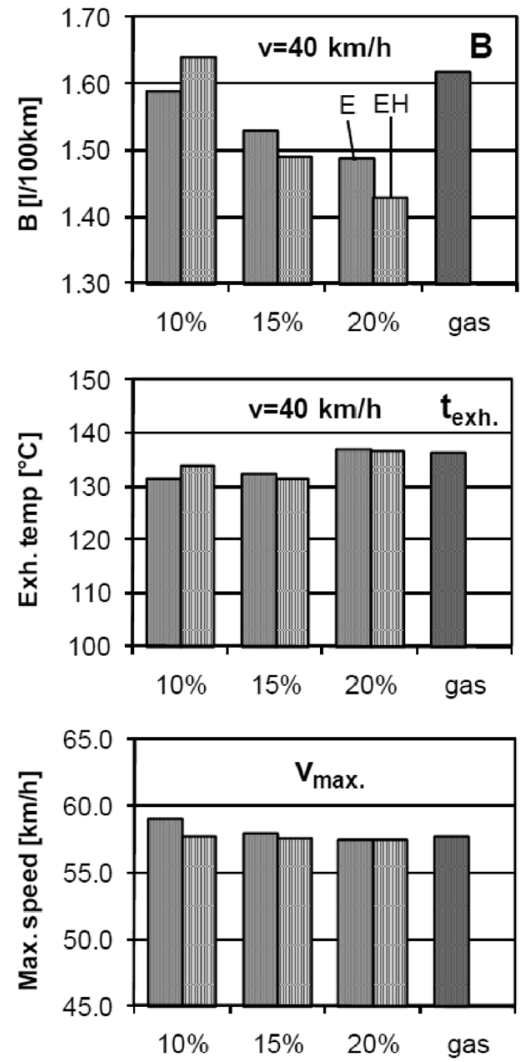

Fig. 16. Fuel consumption and exhaust tempe-ratures (tailpipe) at $40 \mathrm{~km} / \mathrm{h}$ and maximum speed with different fuels. Honda Zoomer

Rys. 16. Zużcie paliwa i temperatury spalin (w przewodzie wylotowym silnika) przy prędkości $40 \mathrm{~km} / \mathrm{h}$ i prędkości maksymalnej dla różnych paliw. Skuter Honda Zoomer
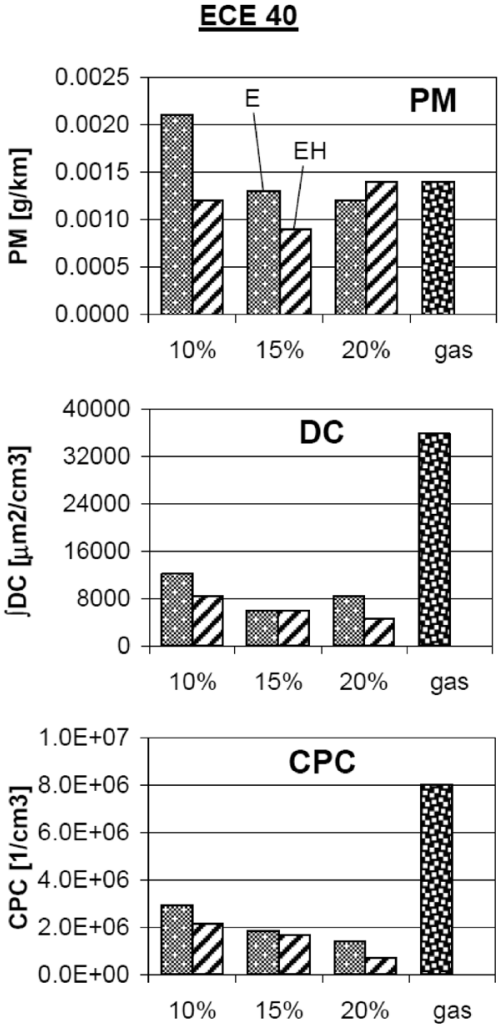

Fig. 17. Particle emissions with different fuels. Honda Zoomer

Rys. 17. Emisje cząstek stalych dla różnych paliw. Skuter Honda Zoomer 


\begin{tabular}{|c|c|c|}
\hline Before tests & CO idl.2.5\% & $\mathrm{n}=2020 \mathrm{rpm}$ \\
\hline After tests & CO idl. $3.1 \%$ & $\mathrm{n}=1950 \mathrm{rpm}$ \\
\hline
\end{tabular}

Figures $15,16 \& 17$ display the most important results: The gaseous components indicate the leaner tuning with increasing share of alcohol - reduction of $\mathrm{CO} \& \mathrm{HC}$, increase of $\mathrm{NO}_{x}$, where the effect of hydrous ethanol is slightly stronger.

The fuel consumption is reduced due to the leaning and increase of the effective engine efficiency.

There is a little impact of the used fuels with ethanol on the exhaust gas temperature (at $40 \mathrm{~km} / \mathrm{h}$ ) and on the maximum speed. With hydrous ethanol there is almost no impact.

The application of fuels with a lower heat value and the shift to leaner air/fuel ratio does not reduce the maximum power very much, because there is en effect of improved engine efficiency.

The PM-emissions are in average much lower, than for the 2 strokers (10-40 times). In this context the indicated differences between "E, EH \& gas" (Fig. 17) cannot be regarded as significant. Nevertheless the higher value with E10 (here in ECE 40) belongs to the first measuring series with ethanol, which at the constant speed indicated much higher PM-\& NP-values with E10. The driving cycle was performed after the constant speed and the effects of higher emissions with E10 are not strong any more. During the repetition of this stationary measurement much lower values with E10 were proved, Fig. 18.
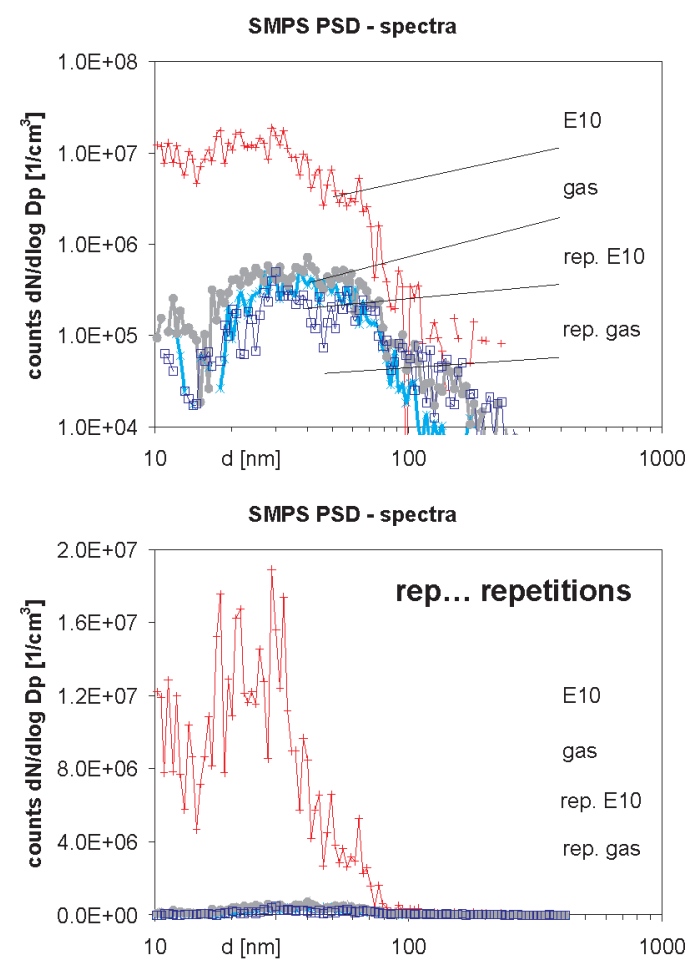

Fig. 18. SMPS particle size distribution spectra at constant speed 40 $\mathrm{km} / \mathrm{h}$, warm, with different fuels. Honda Zoomer - repeated test series Rys. 18. Widma rozkładu wymiarowego cząstek SMPS dla stałej prędkości $40 \mathrm{~km} / \mathrm{h}$, dla rozgrzanego silnika przy różnych paliwach. Skuter Honda Zoomer - powtórzone serie badawcze
Zastosowanie paliw z dolną wartością opałową i przesuniętym stężeniu mieszanki powietrzno-paliwowej w stronę uboższych mieszanek nie powoduje znacznego spadku mocy maksymalnej, ponieważ występuje efekt zwiększonej sprawności silnika.

Średnie wartości emisji PM są znacznie mniejsze niż dla silników 2-suwowych (10-40 razy). W takim kontekście zaznaczone różnice między "E, EH i paliwo gazowe" (rys. 17) nie mogą być uważane za znaczące. Niemniej jednak wyższa wartość dla E10 (w tym przypadku ECE 40) należy do pierwszej pomiarowej serii z etanolem, który przy stałej prędkości wskazywał znacznie wyższe wartości dla cząstek stałych PM i nanocząstek NP dla E10. Cykl jezdny został wykonany przy stałej prędkości i efekt wyższej emisji dla E10 już się więcej nie pojawił. Podczas powtarzania tego stacjonarnego pomiaru dla E10 wystąpiły znacznie niższe wartości (rys. 18). Stało się oczywiste, że wyższe emisje i wyższe stężenia zliczeń nanocząstek w trybie jądrowym dla E10 (w pierwszej serii pomiarowej) były powodowane przez inne czynniki, a nie tylko przez paliwo.

Kondensaty powstałe w sposób niewymuszony mogą pochodzić od siarczanów osadzonych w układzie podczas wcześniejszej pracy silnika zasilanego benzyną, następnie uwolnionych przez etanol (rozpuszczalnik, efekty wymywania) i ostatecznie skroplonych. Przypuszczenie, że w tym zakresie wielkości mogą uwalniać się cząstki stałe należy wykluczyć.

Niezależnie od tego, można stwierdzić, że:

- nie istnieje wpływ paliw alkoholowych na PM,

- emisje nanocząstek NP dla stanów przejściowych są znacznie wyższe niż dla pracy w warunkach ustalonych, - paliwa zmieszane z etanolem pomagają zredukować emisje nanocząstek, szczególnie dla stanów przejściowych.

Odnośnie do powtarzalności wszystkich parametrów występujących w pierwotnych badaniach, w badaniach powtórzonych (niezamieszczonych w niniejszej pracy) należy stwierdzić, że dla wybranych parametrów, jak zużycie paliwa i masa cząstek PM, zmierzone różnice dla różnych paliw mieszczą się w zakresie błędu pomiarowego.

\section{Porównania}

Na rysunku 19 przedstawiono porównanie emisji z silników dwusuwowych i czterosuwowych zasilanych benzyną przy prędkości $40 \mathrm{~km} / \mathrm{h}$. Po raz kolejny przedstawiona jest dobrze znana, wywierająca duże wrażenie, różnica w emisji cząstek. Silnik 2-suwowy ze swoim systemem oleju smarującego ma znacznie wyższe emisje cząstek stałych(PM), zliczenia nanocząstek (NP) oraz sumaryczną powierzchnię aerozolu (DC); to porównanie jest prawdziwe nawet wtedy, gdy silnik 2-suwowy ma ustawioną uboższą mieszankę niż silnik 4-suwowy.

Na rysunku 20 przedstawiono zestawienie najważniejszych efektów spowodowanych przez różne udziały etanolu w trzech badanych skuterach. Zubożenie mieszanki przez etanol wywołuje w skuterze ustawionym na ubogą mieszankę redukcję emisji $\mathrm{NO}_{x}$, wzrost emisji PM i zużycia paliwa (wskutek nieregularności spalania). W przypadku skuterów, które są ustawione na spalanie bogatej mieszanki 
It became clear, that the higher emissions and the higher NP count concentrations in nuclei mode with E10 (in the primary measuring series) were caused by other effects, than the fuel only.

Spontaneous condensates can originate from the sulfates deposited in the system during previous operation with gasoline, than released by ethanol (solvent, washing effects) and finally condensated. A supposition of release of solid particles in this size range must be excluded.

Apart from this fact it can be stated, that:

- there is no influence of alcohol-fuels on PM,

- the NP-emissions at transient operation are much higher, as at steady state operation,

- ethanol blend fuels help to reduce the NP-emissions especially at transient operation.

Regarding the repeatability of all parameters between the original test and the repetitions test (not represented here) it can be stated, that for some parameters, like fuel consumption and particle mass PM the differences measured with different fuels are in the range of measuring dispersion.

\section{Comparisons}

Figure 19 shows the comparison of emissions 2-S \& 4-S with gasoline at $40 \mathrm{~km} / \mathrm{h}$. Once again the very well known impressive difference of particle emissions is demonstrated. The 2-S engine with lost-oil lubrication has much higher emission of particle mass (PM), particle counts (NP) and summary surface of aerosol (DC); this even if the 2-S in this comparison is with leaner tuning, than the 4-S engine.

Figure 20 puts together the most important effects of ethanol rate on the three investigated scooters. The leaning of the mixture by ethanol provokes by the lean tuned scooter a reduction of $\mathrm{NO}_{\mathrm{x}}$ and increase of $\mathrm{PM}$ and fuel consumption (due to irregularities of combustion). By the scooters with rich basic tuning the leaning by ethanol increases $\mathrm{NO}_{\mathrm{x}}$ and reduces $\mathrm{PM}$ and fuel consumption.

The average basic $\lambda$ - tuning (calculated according to SAE J1088) was:

- for Piaggio Typhoon $\lambda=1.0$

- fore Kreidler Florett $\lambda=0.8$

- for Honda Zoomer $\lambda=0.9$

The leaning by use of E15 provokes an increase of the air excess factor $\Delta \lambda=0.05$ to 0.10

\section{Conclusions}

\section{2-S (Piaggio Typhoon - lean)}

The original tuning of the mixture preparation and dosing is influenced by the ethanol containing fuels in the sense of leaner operation. This caused an irregular operation of the engine and a very much deteriorated load response, which would be unacceptable for the market. Generally a lower ethanol rate has to be recommended.

Regarding the legally limited components $\mathrm{CO}, \mathrm{HC}$ and $\mathrm{NO}_{\mathrm{x}}$ three overlapping effects are visible:

- leaning of mixture by increasing ethanol portion,

- lowering the combustion peak temperatures and $\mathrm{NO}_{\mathrm{x}}$ formation with increasing ethanol portion and strengthening of these effects with hydrous ethanol,
SMPS PSD - spectra
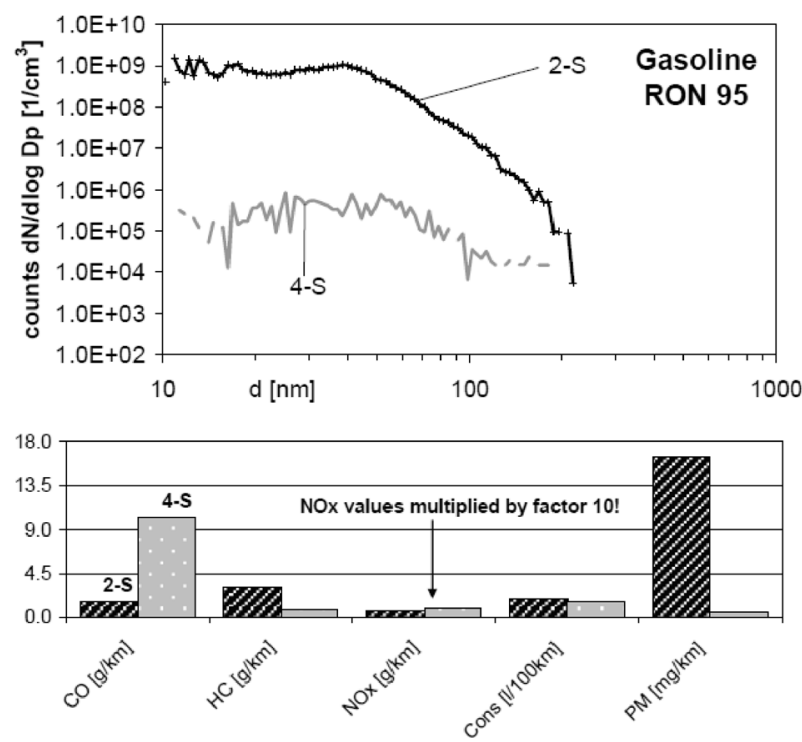

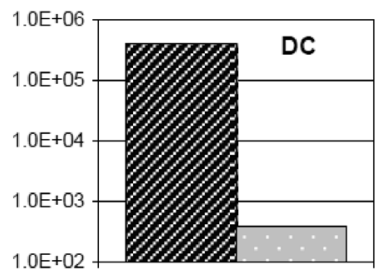

$\mathrm{DC}\left[\mu \mathrm{m}^{2} / \mathrm{cm}^{3}\right]$

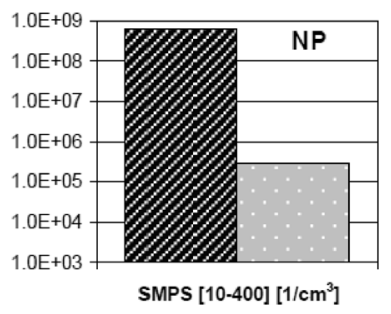

SMPS $[10-400]\left[1 / \mathrm{cm}^{3}\right]$
Fig. 19. Comparison of emissions 2-S \& 4-S at $40 \mathrm{~km} / \mathrm{h}$, warm. 2-S: Piaggio Typhoon, carb. no ox. cat; 4-S: Honda Zoomer, carb. no ox. cat

Rys. 19. Porównanie emisji z silników 2-suwowego oraz 4-suwowego przy prędkości $40 \mathrm{~km} / \mathrm{h}$; silniki ciepte; 2-S: skuter Piaggio Typhoon, gaźnik bez reaktora katalitycznego; 4-S: skuter Honda Zoomer, gaźnik bez reaktora katalitycznego

zubożenie przez etanol zwiększa emisję $\mathrm{NO}_{x}$, obniża emisję PM i zużycie paliwa.

Średnie podstawowe ustawienie $\lambda$ (obliczone wg przepisów SAE J1088) było następujące:

- dla skutera Piaggio Typhoon $\lambda=1,0$

- dla skutera Kreidler Florett $\lambda=0,8$

- dla skutera Honda Zoomer $\lambda=0,9$

Zubożenie spowodowane przez zastosowanie E15 wywołuje wzrost współczynnika nadmiaru powietrza $\Delta \lambda=$ $=0,05$ do 0,10 .

\section{Wnioski}

\section{Silnik dwusuwowy (skuter Piaggio Typhoon - uboga mieszanka)}

Początkowe ustawienie przygotowania mieszanki i dozowania ulega wpływowi paliw zawierających etanol w znaczeniu uzyskania pracy silnika na zubożonej mieszance. Spowodowało to nieregularną pracę silnika i znaczne pogorszenie odpowiedzi silnika na obciążenia, co nie może być zaakceptowane przez rynek. Należy zalecać stosowanie mniejszych udziałów etanolu w paliwie.

W odniesieniu do prawnie limitowanych składników emisji $\mathrm{CO}, \mathrm{HC}$ i $\mathrm{NO}_{\mathrm{x}}$ widoczne są trzy zazębiające się efekty: 


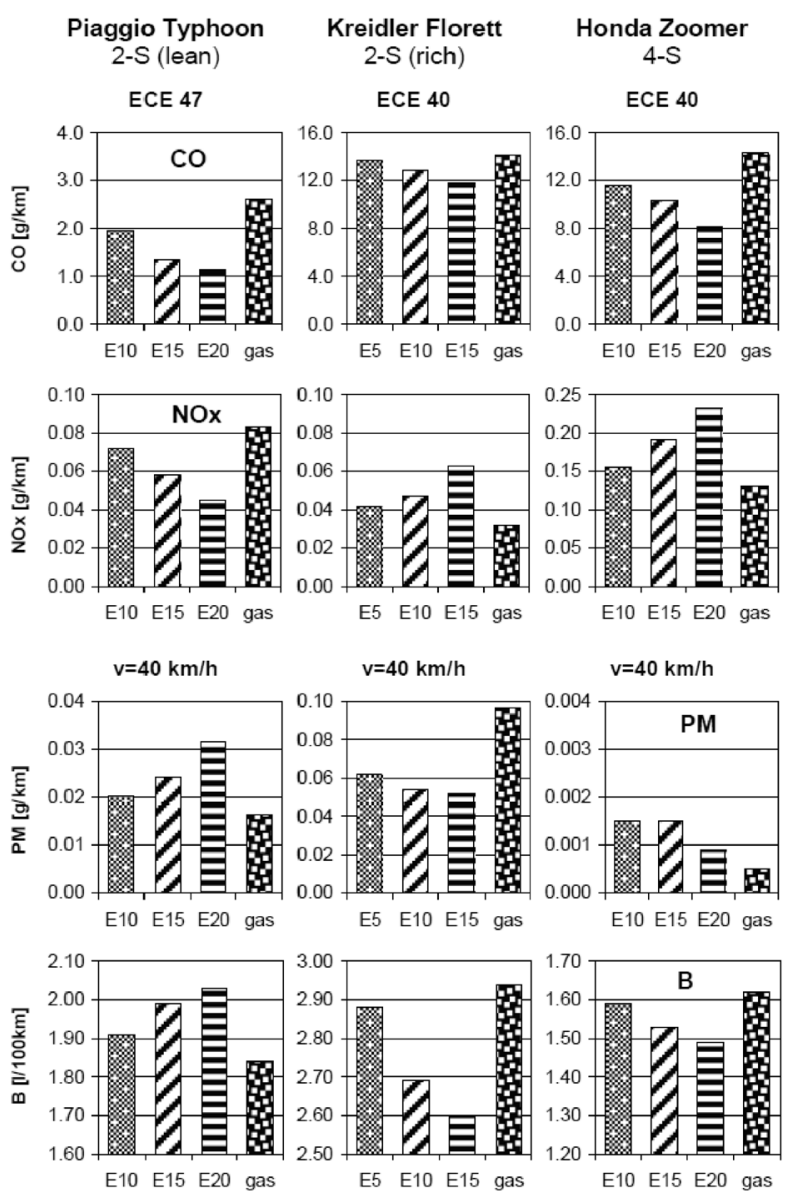

Fig. 20. Influences of ethanol on emission and fuel consumption of the investigated motorbikes

Rys. 20. Wplyw etanolu na emisję i zużycie paliwa dla badanych skuterów

- retarded combustion, increased cyclic irregularities of combustion and increasing HC-emissions with ethanol and with growing ethanol share.

The volumetric fuel consumption increases according to the lower heat value of the blend fuels and the deteriorated irregular combustion.

Particle mass PM and particle counts generally increase with the ethanol fuels, with some tendencies of more increase for hydrous ethanol.

\section{2-S (Kreidler Florett - rich)}

The original tuning of the mixture preparation and dosing is influenced by the ethanol containing fuels in the sense of leaner operation. This caused by this quite rich tuned motorbike advantages in regard of emissions and fuel consumption.

Regarding the legally limited components $\mathrm{CO}, \mathrm{HC}$ and $\mathrm{NO}_{x}$ following effects are visible:

- leaning of mixture by increasing ethanol portion,

- increasing the combustion peak temperatures and $\mathrm{NO}_{\mathrm{x}}$ formation with increasing ethanol portion and strengthening of these effects with hydrous ethanol.

The volumetric fuel consumption is reduced due to the leaning of mixture and increased efficiency with the ethanol blend fuels.
- zubożenie mieszanki przez zwiększenie udziału etanolu, - obniżenie maksymalnych temperatur spalania i tworzenia się $\mathrm{NO}_{\mathrm{x}}$ przy zwiększaniu udziału etanolu oraz nasilenie tych efektów w przypadku wodnego etanolu,

- opóźnione spalanie, zwiększone okresowe nieregularności spalania przy wzrastającej emisji HC dla etanolu i rosnącego udziału etanolu w paliwie.

Objętościowe zużycie paliwa wzrasta odpowiednio do dolnej wartości opałowej mieszanek paliw i zwiększonej nieregularności spalania.

Masa cząstek PM i liczba cząstek wzrastają przy paliwach zmieszanych z etanolem, przy czym występuje tendencja większego wzrostu dla wodnego etanolu.

\section{Silnik dwusuwowy (skuter Kreidler Florett - bogata mieszanka)}

Początkowe ustawienie przygotowania mieszanki i dozowanie ulegają wpływowi paliw zawierających etanol w rozumieniu pracy na mieszance uboższej. Efekt ten spowodowany przez ustawienie skutera do pracy na bogatej mieszance daje korzyść w odniesieniu do emisji i zużycia paliwa.

W odniesieniu do prawnie limitowanych składników emisji CO, $\mathrm{HC}$ i NO widoczne są następujące efekty: - zubożenie mieszanki przez zwiększenie udziału etanolu, - zwiększenie maksymalnych temperatur spalania i tworzenia się $\mathrm{NO}_{x}$ przy zwiększaniu udziału etanolu oraz nasilanie się tych efektów w przypadku wodnego etanolu.

Objętościowe zużycie paliwa ograniczone jest wskutek zubożenia mieszanki i zwiększonej sprawności w przypadku paliw zmieszanych z etanolem.

Masa cząstek PM i liczba cząstek maleją w przypadku paliw etanolowych przy tendencji do większego spadku dla wodnego etanolu.

\section{Silnik czterosuwowy (skuter Honda Zoomer - bogata mieszanka)}

Zdolności trakcyjne badanego skutera były dobre dla wszystkich paliw zmieszanych z etanolem.

Ograniczone elementy gazowe wskazują na ustawienie uboższej mieszanki przy rosnącym udziale alkoholu - redukcja $\mathrm{CO}$ i HC, wzrost $\mathrm{NO}_{\mathrm{x}}$.

Zużycie paliwa jest zmniejszone wskutek zubożenia mieszanki i wzrostu sprawności ogólnej silnika. Nie występuje znaczące obniżenie mocy maksymalnej w badanej dziedzinie dla równoważnego współczynnika.

Odnośnie do emisji PM i NP można stwierdzić, że: - paliwa alkoholowe nie wpływają na PM,

- emisje NP w stanach przejściowych pracy silnika są znacznie większe niż przy pracy w stanach ustalonych,

- paliwa zmieszane z etanolem pomagają ograniczać emisje NP szczególnie w stanach przejściowych. Oznacza to, że alkohol pomaga w lepszym utlenianiu cząstek.

Na początku cyklu roboczego przy paliwach etanolowych występuje uwolnienie pozostałości po wcześniejszej pracy silnika zasilanego benzyną. Te pozostałości zawierające siarczany (z oleju smarującego) są źródłem prekursorów dla niewymuszonej kondensacji w trybie jądrowym, są łatwo wykazywane przez zastosowane metody pomiarowe NP i również widoczne w emisji PM. 
Particle mass PM and particle counts generally decrease with the ethanol fuels, with some tendencies of more decrease for hydrous ethanol.

\section{4-S (Honda Zoomer - rich)}

There was a good drivability of the investigated scooter with all ethanol blends.

The limited gaseous components indicate the leaner tuning with increasing share of alcohol - reduction of $\mathrm{CO}$ \& $\mathrm{HC}$, increase of $\mathrm{NO}_{x}$.

The fuel consumption is reduced due to the leaning and increase of the effective engine efficiency. There is no remarkable reduction of maximum power in the investigated domain of equivalence ratio.

Regarding the PM- and NP-emissions it can be stated, that: - there is no influence of alcohol fuels on PM,

- the NP-emissions at transient operation are much higher, as at steady state operation,

- ethanol blend fuels help to reduce the NP-emissions especially at transient operation. That means, that alcohol helps to better oxidize the particles.

At the beginning of working period with ethanol fuels there is a release ("washing out") of residues from the previous operation with gasoline. These residues containing sulfates (from lube oil) offer precursors for the spontaneous condensates in the nuclei mode (nano range), which is sensitively indicated by the NP measuring methods and is also visible in the PM emissions.

\section{General}

From the present results it can be concluded, that the basic tuning of the engine - not too lean - decides if the influence of leaning by means of ethanol blends has positive, or negative effects. The 2-stroker can be eventually improved by richer basic tuning. The 4-stroker can be deteriorated by the irregularities of combustion, if the basic tuning would be too lean (this can be the case of a modern 4-stokers).

Summarizing: the success of ethanol blend fuels depends on: the engine type (2-S, 4-S), the basic tuning of the engine (air-fuel-ratio) and the ethanol content.

There are no significant differences of results between the blends with pure ethanol (E), or hydrous ethanol (EH), except of some cases, where EH improves slightly the emissions (CO, HC, PM, NP) and reduces the fuel consumption.

The present investigations did not concern the durability of parts exposed to the chemical influences of ethanol. Also the cold startability, particularly in extreme conditions and the lube oil dilution were not addressed.

According to the fuel supplier, there is no danger of phase separation of the hydrous ethanol in the used temperature range.

\section{Acknowledgements}

The authors would like to express their gratitude for the support of the project to BAFU (Swiss EPA), Dr. M. Schiess and to the Process Design Center B.V.NL and TU Delft.

\section{Ogólne podsumowanie}

Na podstawie przedstawionych wyników można wnioskować, że podstawowe ustawienie silnika - na niezbyt ubogą mieszankę - decyduje, czy uzyskane zubożenie mieszanki za pomocą paliw zmieszanych z etanolem ma pozytywne bądź negatywne skutki. Silnik dwusuwowy można usprawnić przez bazowe ustawienie bogatszej mieszanki. Praca silnika czterosuwowego może ulegać pogorszeniu przez nieregularności spalania wtedy, gdy podstawowe ustawienie byłoby zbyt ubogie (może to dotyczyć współczesnych silników czterosuwowych).

Podsumowując: sukces stosowania paliw mieszanych z etanolem zależny jest od: typu silnika (dwu- lub czterosuwowy), podstawowego ustawienia silnika (stężenia mieszanki paliwowo-powietrznej) oraz zawartości etanolu.

Nie występują znaczące różnice w wynikach uzyskanych dla mieszanin paliwowych z czystym etanolem (E) lub z etanolem uwodnionym (EH), z wyjątkiem przypadków, w których EH nieznacznie poprawia emisję (CO, HC, PM, NP) oraz obniża zużycie paliwa.

Obecne badania nie uwzględniały trwałości części narażonych na chemiczne działanie etanolu. Badania nie były ukierunkowane również na zagadnienia stabilności zimnego startu w warunkach ekstremalnych oraz rozcieńczania oleju smarującego.

Zgodnie z opinią dostawcy paliwa nie występuje niebezpieczeństwo rozdzielenia faz uwodnionego etanolu przy stosowanym zakresie temperatur.

\section{Podziękowania}

Autorzy wyrażają wdzięczność za pomoc przy realizacji projektu następującym osobom i instytucjom: Federalnemu Urzędowi ds. Środowiska BAFU (Szwajcarski oddział EPA) i dr. M. Schiessowi, Ośrodkowi Process Design Center B.V.NL, a także TU Delft.

Paper reviewed/Artykut recenzowany

\section{Nomenclature/Skróty i oznaczenia}

AFHB Abgasprüfstelle der Fachhochschule, Biel CH (Lab. For Exhaust Gas Control, Univ. of Appl. Sciences, BielBienne, CH)/Laboratorium Kontroli Emisji Spalin Uniwersytetu Nauk Stosowanych w Biel-Bienne, Szwajcaria

BAFU Bundesamt für Umwelt (Swiss EPA)/Federalny Urzad ds. Środowiska (Szwajcarski oddziat EPA)

C Carburetor/gaźnik

Carb Carburetor/gaźnik

CMD count median diameter/obliczona środkowa wartość średnicy

CPC condensation particle counter/kondensacyjny licznik czastek statych

CVS constant volume sampling/stała objętość próbkowanych spalin 
DC diffusion charging sensor/czujnik rozcieńczenia ładunku

DF dilution factor/współczynnik rozcieńczenia

DMA differential mobility analyser/różnicowy analizator rozmiaru cząstek oparty na ocenie ich zmienności ruchowej

E pure ethanol (energy only Fig. 6a)/czysty etanol (jedynie energia rys. 6a)

EC elemental carbon/wegiel pierwiastkowy

EH hydrous ethanol/etanol uwodniony

FHB Fachhochschule Biel/Uniwersytet Nauk Stosowanych w Biel-Bienne

Gas gasoline leed-free, RON 95 (base fuel)/benzyna 95

MD minidiluter/minitunel rozcieńczajacy

ME Matter Engineering, CH/Inżynieria Materiałowa, Szwajcaria

NanoMet minidiluter + PAS + DC $(+\mathrm{TC}) /$ minitunel rozcieńczajacy + fotoelektryczny czujnik aerozolu + czujnik rozcieńczenia tadunku (+ termoklimatyzator)

NP nanoparticulate $(<1 \mu \mathrm{m})$ /nanoczastki $(<1 \mu \mathrm{m})$

OC organic carbon/węgiel organiczny
PAS photoelectric aerosol sensor/fotoelektryczny czujnik aerozolu

PM particulate matter, particulate mass/czastka stata

PMP particle measuring program (of the ECE GRPE)/program pomiaru czastki (wg ECE GRPE)

PSD particles size distribution/rozklad wymiarowy cząstek

$\mathrm{r} \quad$ rich basic tuning/tuning podstawowy w kierunku wzbogacenia mieszanki

SAS secondary air system/system powietrza wtórnego

SMPS scanning mobility particles sizer/skaningowy analizator wymiarowy czastek statych oparty na analizie ruchliwości elektrycznej czastek

SOF soluble organic fraction/frakcja rozpuszczalna czastki statej

TC thermoconditioner, total carbon/termoklimatyzator, catkowita ilość węgla

TP tailpipe/przewód wylotowy silnika

TPN total particle number [\#/km]/calkowita liczba czastek [\#/km]

2-S 2 stroke engine/silnik dwusuwowy

4-S 4 stroke engine/silnik czterosuwowy

\section{Bibliography/Literatura}

[1] Czerwinski J., Comte P., Napoli S., Wili Ph.: Summer Cold Start and Nanoparticulates of Small Scooters. Report B086 for BUWAL (SAEFL) Bern, Lab. For Exhaust Gas Control, Univ. of Appl. Sciences, Biel-Bienne, Switzerland, Nov. 2000. SAE Techn. Paper 2002-01-1096.

[2] Czerwinski J., Comte P.: Limited Emissions and Nanoparticles of a Scooter with 2-stroke Direct Injection (TSDI). SAE Techn. Paper 2003-01-2314.

[3] Czerwinski J., Comte P., Reutimann F.: Nanoparticle Emissions of a DI 2-Stroke Scooter with varying Oil- and Fuel Quality. SAE Techn. Paper 2005-01-1101.

[4] Czerwinski J., Comte P., Larsen B., Martini G., Mayer A.: Research on Particle Emissions of modern 2-S Scooters. SAE Techn. Paper 2006-01-1078.

[5] Czerwinski J., Comte P., Astorga C., Rey M., Mayer A., Reutimann F.: (Nano) Particle from 2-S Scooters: SOF / INSOF; Improvements of Aftertreatment; Toxicity. AFHB, JRC, TTM, BAFU, SAE Techn. Paper 2007-01-1089.

[6] Czerwinski J., Comte P., Violetti N., Landri P., Mayer A., Reutimann F.: Catalyst Aging and Effects on Particle Emissions of 2-Stroke Scooters. SAE Techn. Paper 2008-01-0455.

[7] Bergström K., Melin S-A., Coleman J.: General Motors Powertrain: The New ECOTEC Turbo BioPower Engine from GM Powertrain - Utilizing the Power of Nature's resources. 28. Internationales Wiener Motorensymposium 2007, Bd.2, S. 47.

Prof. Jan Czerwiński, DEng. - Laboratorium for IC-Engines and Exhaust Gas Control, University of Applied Sciences Biel-Bienne, Switzerland.

Prof. dr Jan Czerwiński - Laboratorium Silników Spalinowych i Emisji Spalin, Uniwersytet Nauk Stosowanych w Biel-Bienne, Szwajcaria. e-mail: jan.czerwinski@bfh.ch

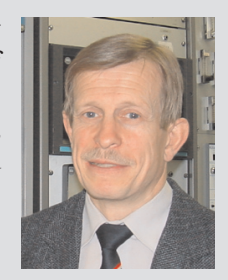

Pierre Comte - AFHB, University of Applied Sciences, Biel-Bienne, Switzerland.

Pierre Comte - Uniwersytet Nauk Stosowanych, Biel-Bienne, Szwajcaria.

e-mail:pierre.comte@bfh.ch
[8] Bergström K., Nordin H., Königstein A., Marriott C.D., Wiles M. A.: ABC - Alcohol Based Combustion Engines - Challenges and Opportunities. 16. Aachener Kolloquium Fahrzeugund Motorentechnik 2007, Bd.2, S. 1031.

[9] Kawai T., Tsunooka T., Chiba F., Uda H., Sonoda,Y., Toyota Motor Corporation, Japan: Effect of high Concentration Ethanol on SI Engine Cold Startability and Emissions. 16. Aachener Kolloquium Fahrzeug- und Motorentechnik 2007.

[10] DuMont R. J., Cunningham L.J., Oliver M.K., Studzinski W.M., Galante-Fox J M.: Controlling Induction System Deposits in Flexible Fuel Vehicles Operating on E85. SAE Techn. Paper 2007-01-4071.

[11] Galante-Fox J.M., Von Bacho P., Notaro C., Zizelman J.:E85 Fuel Corrosivity: Effects on Port Fuel Injector Durability Performance. SAE Techn. Paper 2007-01-4072.

[12] CONCAWE ... Conservation of Clean Air und Water in Europe, Brussel, www.concawe.org.

[13] Gottschalk A.: Gasoline Blending with Hydrous Ethanol. 7th International Colloquium "Fuels", Technische Akademie Esslingen TAE, Jan. 14-15, 2009.

[14] Hydrous Ethanol Blends. HE Blends B.V. www.heblends.com

[15] Czerwinski J., Comte P., Mayer A., Reutimann F., Zürcher D.: Reduction Potentials of Particle Emissions of 2-S Scooters with Combinations of Technical Measures. FISITA, Paper F200809-014, Congress Proceedings Vol. IV, p. 100, ATZ/ATZ auto technology, Springer Automotive Media, Wiesbaden, D.

Andreas Mayer, MEng. - Technik Thermische Maschinen (TTM), Switzerland.

Inż. Andreas Mayer - pracownik Termodynamicznej Techniki Maszyn (TTM), Szwajcaria. e-mail: ttm.a.mayer@bluewin.ch

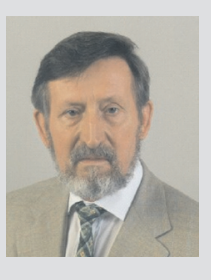

Felix Reutimann - BAFU, Federal Office of Environment, Switzerland.

Felix Reutimann - BAFU, Federalne Biuro Ochrony Środowiska, Szwajcaria.

e-mail:felix.reutimann@bafu.admin.ch 